\section{Simultaneous Determination of Silica and Gallium in Red Mud}

Simultanbestimmung von Siliciumdioxid und Gallium in Rotschlamm

Best. von Siliciumdioxid und Gallium in Rotschlamm; Aufschlußmethode

\section{R.S. Thakur and B.R. Sant}

Regional Research Laboratory, Bhubaneswar, Orissa, India

Received October 10, 1972; revised March 12, 1973

Solizic and Marijanovic [1] have reported the use of ammonium chloride in the treatment of bauxites and red mud. A series of experiments were carried out in these Laboratories on the decomposition of a red mud sample obtained from an indigenous alumina plant with a view to determine the most suitable ratio of sample to ammonium chloride for a precise and simultaneous determination of silica and gallium.

\section{Polarographische Bestimmung von Äthylendiamin in Gegenwart von Ammoniak}

Polarographic Determination of Ethylene Diamine in the Presence of Ammonia

Best. von Äthylendiamin neben Ammoniak; Polarographie

J. Bogaczek and M. Jaworski

Institut für Schwere Organische Synthese

Blachownia Sl., Polen

Eingegangen am 27. Juli 1972;

Neue Fassung 18. November 1972

Zur Bestimmung von Äthylendiamin neben Ammoniak wurde eine polarographische Methode ausgearbeitet, die auf der Komplexbildung mit Kobaltsalzen beruht. Der Äthylendiamin-Kobaltkomplex ergibt an der Hg-Tropfelektrode zwei kathodische und eine anodische Stufe. Die erste kathodische Stufe, die proportional zur Äthylendiaminkonzentration ist,
The recommended ratio is $1: 2$ on a 0.5 or $1.0 \mathrm{~g}$ red mud sample.

The sample was treated with $25 \mathrm{ml}$ of $\mathrm{HCl} / \mathrm{HNO}_{3} / \mathrm{H}_{2} \mathrm{SO}_{4}$ (3:1:1) mixture and heated to dryness. To the residue, $5 \mathrm{ml}$ $\mathrm{HCl}$ and 1 or $2 \mathrm{~g}$ of $\mathrm{NH}_{4} \mathrm{Cl}$ were added and again taken to dryness. On leaching with $\mathrm{HCl}(1: 1), \mathrm{SiO}_{2}$ was filtered and analysed gravimetrically, whereas the filtrate was analysed for $\mathrm{Ga}$ colorimetrically with crystal violet.

Good results were obtained for red mud samples which contained $6.46 \% \mathrm{SiO}_{2}$ and $60 \mathrm{ppm} \mathrm{Ga}$.

The authors thank Prof. P. K. Jena, Director, for his keen interest in the work and Messrs. Madras Aluminium Company for the sample of red mud.

\section{Reference}

1. Solzic, Z., Marijanovic, V.: Chim. Anal. (Paris) 50, 122 (1968); 52, 285 (1970).

Dr. B. R. Sant

Regional Research Laboratory

Bhubaneswar-4

Orissa, India wurde zur Bestimmung benutzt. Es wurde gefunden, daß ein 5 facher Kobaltüberschuß vorhanden sein muß, um reproduzierbare Werte zu erhalten. In $A b$ wesenheit von Ammoniak treten nur sehr kleine Stufen auf, jedoch reicht schon die in der Grundlösung vorhandene Menge $(0.5 \mathrm{M})$ aus, um auswertbare Stufen zu erhalten. In den untersuchten Proben waren außer Ammoniak auch Harnstoff sowie Cycloäthylenharnstoff vorhanden, die jedoch die Bestimmung nicht beeinflußten. Der relative Fehler betrug im Durchschnitt $\pm 7,0 \%$.

Arbeitsweise. In einem $50 \mathrm{ml}-\mathrm{Kolben}$ versetzt man die Probemenge, die etwa $10 \mathrm{mg}$ Äthylendiamin enthält, mit

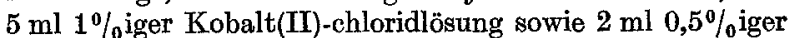
Gelatinelösung und füllt mit Grundlösung $\left(0,5 \mathrm{M} \mathrm{NH}_{4} \mathrm{Cl}\right.$; $0,5 \mathrm{M} \mathrm{NH}{ }_{4} \mathrm{OH}$ ) zur Marke auf. Nach Entlüftung mit Stickstoff ( $\sim 15 \mathrm{~min}$ ) nimmt man das Polarogramm von $-0,2$ bis -1 V auf $(t 3 \mathrm{sec} ; m 2,9 \mathrm{mg} / \mathrm{sec} ; h 210 \mathrm{~mm} \mathrm{Hg})$. Die Resultate entnimmt man einer entsprechend aufgestellten Eichkurve.

Dipl.-Ing. J. Bogaczek

Institut Ciężkiej Syntezy Organicznej

Blachownia \$1., Polen 